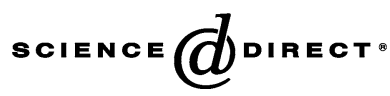

Forest Policy and Economics xx (2005) xxx-xxx
Forest Policy

and

Economics

www.elsevier.com/locate/forpol

\title{
Entrepreneurship in value chains of non-timber forest products
}

\section{Abstract}

\author{
Dirk Willem te Velde ${ }^{\mathrm{a}, *}$, Jonathan Rushton ${ }^{\mathrm{b}}$, Kathrin Schreckenberg ${ }^{\mathrm{c}}$, \\ Elaine Marshall ${ }^{\mathrm{d}}$, Fabrice Edouard ${ }^{\mathrm{e}}$, Adrian Newton ${ }^{\mathrm{f}}$, Erik Arancibia ${ }^{\mathrm{g}}$ \\ a Overseas Development Institute, 111 Westminster Bridge Road, London SE1 7JD, UK \\ ${ }^{\mathrm{b}}$ CEVEP, Bolivia \\ ${ }^{\mathrm{c}}$ Overseas Development Institute, UK \\ ${ }^{\mathrm{d}} \mathrm{UNEP}-W C M C, U K$ \\ ${ }^{\mathrm{e}}$ Methodus, Mexico \\ ${ }^{\mathrm{f}}$ University of Bournemouth, UK \\ ${ }^{\mathrm{g}}$ Independent, Bolivia
}

Entrepreneurship and innovation by actors in the market for non-timber forest products (NTFPs) cannot be fully understood without a proper understanding of the position and behaviour of actors in the value chain of NTFPs. This paper places the market for NTFPs in the emerging literature on value chains which has, so far, lacked a detailed analysis of NTFPs. Our analysis reveals that certain key entrepreneurs are a driving force of success throughout several NTFP value chains in both Bolivia and Mexico. Where market information is scarce, e.g. where producers are distant from consumers, key entrepreneurs often govern entire value chains.

We argue that certain entrepreneurs are key to spreading success throughout the value chains of selected NTFPs offsetting potential negative consequences such as exploitation of more upstream actors (e.g. collectors and processors) in the value chains. Typical examples include the shopkeeper/organisation in Santa Cruz, Bolivia, who sources woven palm products from and supports several producers, and the entrepreneur in Mexico who established links between mushroom pickers in rural communities and brokers and consumers in Japan. Rather than criticising the monopolistic position of individuals, it is important to understand how the activity of key entrepreneurs can be supported in spreading successful commercialisation further and where necessary control negative impacts of their role. Our analysis indicates that policies to support commercialisation of the case study NTFPs would also need to be tailored to each value chain.

(C) 2005 Elsevier B.V. All rights reserved.

\footnotetext{
* Corresponding author.

E-mail address: dw.tevelde@odi.org.uk (D.W. te Velde).
}

1389-9341/\$ - see front matter (C) 2005 Elsevier B.V. All rights reserved.

doi:10.1016/j.forpol.2005.06.010 


\section{Introduction}

The paper presents an analysis of non-timber forest product (NTFP) ${ }^{1}$ commercialisation using value chain analysis as used, e.g. by Gereffi (1999). The analysis is useful in determining the importance of key individuals in driving entrepreneurship and innovation in the market for NTFPs. Understanding these issues in turn is required for the design of appropriate policies and development interventions, which are often based on the assumption that poor and politically powerless extractors suffer from high levels of exploitation by intermediaries (Neumann and Hirsch, 2000).

Value chain analysis is a methodology which is different from other market chain analysis methodologies such as the chain analysis advanced by Porter (1985). Porter also analysed value chains, the activities within and around a firm, but focused on the analysis of the competitiveness of a particular firm. ${ }^{2}$ Global value chain analysis does not focus on the competitiveness of a particular firm, but rather on how relations amongst firms are governed, i.e. on the efficiency of the chain as a whole.

Value chain analysis is emerging as a useful tool that has already led to new practical insights in the markets for textiles and clothing (Gereffi, 1999), fresh fruits and vegetables (Dolan et al., 1999), commodities such as tea and coffee, and wooden furniture in the case of the forestry sector (Kaplinsky et al., 2003). Recent developments in value chain analysis relate to describing a typology of governance in value chains, the factors that explain this typology (Gereffi et al., 2003) and the effects of certain governance forms.

\footnotetext{
${ }^{1}$ For the purposes of this paper, we define non-timber forest products as natural products (excluding animal or wood-based products) collected from more or less managed forest resources and, in some cases, with a proportion harvested from cultivated sources.

${ }^{2}$ Porter distinguishes between primary activities concerned with delivering a product (inbound logistics, operations, outbound logistics, marketing and sales, and services) and support activities (procurement, human resource management, technology development, and infrastructure). The costs or competitiveness of the firm depends on its ability to manage linkages between all of these activities.
}

There have to date been few attempts to use value chain analysis to obtain new information about what drives entrepreneurship in markets for NTFPs. This paper tries to fill this gap and is based on the result of a multidisciplinary, multi-year research project on successful commercialisation of NTFPs. It examines value chains some of which are international but do not enter into several countries (as global would imply), but the global value chain literature would apply.

The paper is divided into the following sections:

- Section 2 will discuss issues in global value chain (or GVC, as referred to in the theory) analysis, including a typology of governance of value chains.

- Section 3 discusses the research methods used.

- Section 4 summarises the value chain analysis for the 10 NTFPs studied and presents a more detailed analysis of three NTFPs that show clearly the importance of individual entrepreneurs in development of the entire value chain.

- Section 5 examines whether certain types of governance dominate the NTFP value chains we examined in our research.

- Section 6 examines more closely the relationship between governance and entrepreneurship in the three selected case studies.

- Section 7 presents the conclusions from the research.

\section{Issues in global value chain analysis}

Primary products such as NTFPs are linked to final consumers through so-called value chains. A value chain describes the full range of activities required to bring a product or service from conception, through the intermediary phases of production (transformation and producer services inputs), delivery to final consumers and final disposal after use (Kaplinsky, 2000). A value chain can be called global when it involves different stakeholders at different stages in different countries. A chain consists of a number of different actors each specialising in different functions, but linked through certain ways of cooperation in a network. A value chain can be distinguished from the ordinary market place by the degree to which firms in a chain cooperate, and value 
111 chain analysis describes governance and power-rela-

112 tions in the chain, and how this affects success for

113 various actors in a chain.

114 The analysis of global value chains has emerged 115 over the past 5-10 years. Three issues in value chain 116 analysis are of particular importance to the current 117 paper.

118

119 - How useful are value chains as a tool for describ-

120 ing the commercialisation of NTFPs?

121 - What type of value chain governance should we 122 expect for NTFPs?

123 - What is the link between governance and entrepre125 neurship in NTFP value chains?

\section{2.1. Value chains as a descriptive tool}

127 At the most basic level, value chain analysis can 128 be seen as a methodological tool (Kaplinsky and 129 Morris, 2001) for describing markets for NTFPs. 130 The most common way is to draw a map of the 131 different production blocks and the interrelationships 132 amongst them. Another way is to compute profit 133 margins or levels of success at each stage in the 134 value chain. The paper will show that value chain 135 analysis is an important methodology in describing 136 markets for NTFPs and identifying key issues in 137 policy and aid interventions. It can complement the 138 multivariate analysis used by Ruiz Pérez and Byron 139 (1999) and expanded upon by Ruiz Pérez et al. 140 (2004) to describe the role of NTFPs in household 141 livelihood strategies.

\section{2.2. Governance of value chains}

143 Governance of value chains relates to the type of 144 coordination amongst dispersed but linked production 145 systems. Gereffi (1999) introduced two different types 146 of governance in value chains (which he called com147 modity chains). Buyers undertake coordination in 148 "buyer-driven" value chains, while producers play a 149 key role in "producer-driven" value chains. Buyer150 driven chains refer to industries in which large retai151 lers, marketers and branded manufacturers play the 152 pivotal roles in setting up decentralised production 153 networks. The specifications for the production net154 works are set by the large retailers or marketers that 155 source the goods.
Gereffi et al. (2003) elaborate further and distinguish between five types of governance:

1. Markets. There are repeated transactions amongst different actors but the costs of switching to new actors are low.

2. Modular value chains. Suppliers make products to a customer's specifications. Suppliers take responsibility for competencies surrounding process technology and incur few transaction-specific investments.

3. Relational value chains. There is mutual dependence regulated through reputation, social and spatial proximity, family and ethnic ties, etc.

4. Captive value chains. Small suppliers depend on much larger buyers for their transactions and face significant switching costs and are, therefore, "captive". These networks are frequently characterised by a high degree of monitoring and control by the lead firm, creating dependence on the suppliers.

5. Hierarchy. This implies vertical integration with managerial control.

Gereffi et al. (2003) go on to argue that the following three factors explain which type of governance can be expected:

1. Complexity of inter-firm knowledge transfer required for transactions;

2. The extent to which this information and knowledge can be codified and transmitted efficiently without transaction specific investment; and

3. Capabilities of actual and potential suppliers to meet the requirements of the buyer.

Table 1 presents the probability that different forms of governance will be associated with the three factors described.

For instance, governance by ordinary market transactions will occur when product specifications are relatively simple, transactions are simple and easily codified and suppliers have the capability to make the relevant products with little input from buyers so that there is nothing specific about inter-firm relationships. At the other extreme, we would expect a hierarchical governance structure (in-house production) when product specifications are based on tacit knowledge and
156 
t1.1 Table 1

t1.2 What type of governance is likely?

Governance Complexity Ability/Potential Capabilities
of inter-firm of codification of suppliers knowledge of knowledge transfer

\begin{tabular}{|c|c|c|c|c|}
\hline $\mathrm{t} 1.4$ & Markets & Low & High & High \\
\hline $\mathrm{t} 1.5$ & $\begin{array}{l}\text { Modular value } \\
\text { chains }\end{array}$ & High & High & High \\
\hline $\mathrm{t} 1.6$ & $\begin{array}{l}\text { Relational value } \\
\text { chains }\end{array}$ & High & Low & High \\
\hline $\mathrm{t} 1.7$ & $\begin{array}{l}\text { Captive value } \\
\text { chains }\end{array}$ & High & High & Low \\
\hline $\mathrm{t} 1.8$ & Hierarchy & High & Low & Low \\
\hline
\end{tabular}

t1.9 Source: Gereffi et al. (2003).

204 cannot be codified, while competent suppliers are 205 absent.

206 In between these extremes, modular value chains 207 arise when the specifications applying to more com208 plex products are easily codified. Relational value 209 chains arise when specific knowledge is exchanged, 210 dealing with complex products and/or market infor211 mation, and there is a low potential to codify product 212 specifications, while lead firms are motivated to 213 access suppliers with high capabilities. Finally, cap214 tive value chains can arise when it is easy to codify 215 product specifications through detailed instructions in 216 the context of complex products and where there are 217 suppliers with lower capabilities. Low capability sup218 pliers require instructions from lead firms, fostering 219 dependence and the lock-in of suppliers, while other 220 potential suppliers may be excluded from the benefits 221 of the lead firm's efforts. Suppliers incur significant 222 switching costs and are "captive" as inter-firm rela223 tionships contain specific transactional assets. In cap224 tive value chains, suppliers are often locked into 225 simple tasks such as production according to specifi226 cation, while lead firms are involved in more complex 227 activities such as design, logistics, and process tech228 nology upgrading.

229 This framework was developed in the context of 230 bicycles, apparel, fresh vegetables, and electronics 231 (Gereffi et al., 2003). We will examine the value of 232 the framework in the context of explaining govern233 ance in NTFP value chains. NTFPs are the subject of 234 great current interest among conservation and devel235 opment organisations (Ruiz Pérez and Arnold, 1996; 236 Wollenberg and Ingles, 1998; Neumann and Hirsch,
2000). Not only do they contribute to improving many rural livelihoods but, where they are harvested in a sustainable manner, they may also contribute to conserving the resource (Belcher and Schreckenberg, 2003). As more research is carried out on individual NTFPs, there is growing awareness that the governance structures that dominate NTFP value chains may be highly inequitable, the best-known example being the debt peonage of the wild rubber harvesters in the Brazilian Amazon (Schwartzman, 1992). Intermediaries or entrepreneurs are undoubtedly the most maligned actors in the value chain (Schreckenberg, 2003). Yet some studies suggest that the role of 'middlemen' has been underestimated (Padoch, 1992) and that it is a mistake to try to bypass them (Corry, 1993, cited in Neumann and Hirsch, 2000). More appropriate interventions in NTFP commercialisation require a better understanding of NTFP value chain governance, particularly relating to the roles of intermediaries and their relationships with other actors (Humphrey, 2000; Maynard et al., 2001).

\subsection{Linking governance to success and entrepreneur-} ship in value chains

Humphrey and Schmitz (2001) found that governance of global value chains matters. For instance, if global value chains are governed by a few lead firms or entrepreneurs, market access for suppliers is dependent not only on the efficiency of the supply capabilities, but also on how suppliers fit into the strategies of these lead firms. The type of governance also affects the distribution of gains. When lead firms govern a chain they are able to determine where high return activities (often intangible activities such as marketing and R\&D) and low-return activities are located along the chain.

Value chain governance can contribute to the success of a value chain by influencing how production capabilities are upgraded. Value chain analysis considers four types of upgrading (Kaplinsky and Morris, 2001). Process upgrading is associated with increases in the efficiency of production processes within or between stages of the value chain. Product upgrading leads to improvement and introduction of products. Functional upgrading changes the mix of activities and functions conducted within the value chain or firm (for example, taking responsibility for marketing 
283 and design, improving transactions, and optimal redis284 tribution of activities). Finally, chain upgrading 285 involves moving to a new value chain.

286 Taking the captive value chain as one example, 287 there are both opportunities and barriers to achieving 288 success for suppliers by upgrading in such chains. A 289 classic example (outside NTFP markets) where 290 upgrading helped to raise the level of entrepreneurship 291 of suppliers is the textile and clothing value chain 292 present in several Asian countries (Gereffi, 1999). 293 East Asian countries upgraded production processes 294 and functions (from simple assembly to marketing and 295 design) in the context of 'triangle manufacturing', 296 whereby developed country buyers place orders with 297 East Asian countries, who in turn became successful 298 entrepreneurs and outsourced parts of the production 299 to low-wage countries (China, Indonesia, Vietnam). 300 East Asian countries are now much more involved in 301 design and other downstream functions.

302 However, other countries (e.g. Central American 303 countries) are locked into the upstream part of the 304 value chain with few incentives (from lead firms 305 lower down the chain) to upgrade. UNIDO (2002) 306 discusses the global value chain of wooden furniture 307 in South Africa where pine furniture has faced 308 increasing price competition putting pressures on 309 export prices. Products were also considered of low 310 quality and poor delivery reliability. The global buyer 311 in this captive value chain did not consider increasing 312 the efficiency of this manufacturing stage and 313 switched to more competitive East Asian suppliers, 314 while South Africa had to focus on a different value 315 chain using environmentally friendly wood (and 316 upgraded in that way).

317 Understanding the type of governance is important, 318 therefore, when developing policy and directing tech319 nical assistance. Policy initiatives may affect a number 320 of firms more intensively when they are closely 321 related. Technical assistance programmes can be 322 made more efficient by targeting lead firms to the 323 benefit of suppliers upstream. Where there are a 324 small number of lead firms or individuals that control 325 a chain, there is a need for monitoring and perhaps 326 regulation to ensure that such firms or individuals are 327 not abusing their position of power within a chain. In 328 many developing countries, where NTFPs are impor329 tant to poor families, such monitoring and regulation 330 policies are rarely well implemented.

\section{Methods}

331

The project investigated the commercialisation of NTFPs in Bolivia and Mexico. Data collection and analysis methods were developed within a framework provided by six research hypotheses. The first four examined the impact of NTFP commercialisation on the poorest producers, processors and traders; women; the resource; and access to the resource. The two hypotheses of most relevance to this paper were:

- The successful commercialisation of an NTFP depends critically on the existence of an accessible market, potential demand, and the access by producers, processors and traders to market information.

- The success of poor producers, collectors, processors and traders in NTFP commercialisation depends critically on the number of suppliers and demanders, capacity to exert market power, barriers to entry, and the degree of vertical and horizontal integration.

In each country the policies relating to NTFP commercialisation were reviewed. Ten products were selected for detailed study from a larger initial group (see Marshall et al., 2003 for full list) based on the criteria that the NTFP was:

- traded beyond the village of collection;

332

- of interest to the project's partner NGOs (all of which were development NGOs with a secondary interest in research);

- not a fresh fruit; and

- traded from two similar communities via different marketing networks.

For each product a structured 'market' report was written based on a combination of secondary data and key informant interviews. These reports described the main market chains for the product, beginning in the study communities and tracking information as far downstream to the final consumer as possible. As some of the products were marketed in very different ways (e.g. fresh mushrooms for local consumption, dried mushrooms for the national market and fresh mushrooms for export),
360

361

362

363

364

365

366

367

368

369

370

371

372

373

374

375

376

377 
t2.1 Table 2

t2.2 Some key attributes of case study value chains

Location Product

\section{San Antonio}

Cuajimoloyas Oaxaca, Mexico

Santa Martha Latuvi, Oaxaca, Mexico

\section{Fresh mushrooms}

Dried mushrooms

Fresh matsutake mushrooms

Arroyo Blanco and Agua Pescadito, Oaxaca, Mexico

Pita fibre sold to artisan
for embroidering belts

for

Soyate palm fibres

woven into hats

$\mathrm{t} 2.8$

La Esperanza and Topiltepec, Guerrero, Mexico

Monte Tinta and Nueva Camedora palm fronds Santa Flor, Oaxaca, Mexico

t2.10 Yagavila and Tiltepec, Oaxaca, Mexico

t2.11 La Esperanza and Topiltepec Guerrero, Mexico sold as floral greens

Tepejilote palm inflorescences sold as traditional food Maguey 'heads' distilled to produce mezcal (traditional alcohol)

Organic wild cocoa

t2.12 Carmen del Emero, La Paz, Bolivia

t2.13 San Silvestre, La Paz, Bolivia

t2.14 Tomachi, La Paz, Bolivia
Organic wild cocoa paste

Local and some national

Natural rubber latex for National specialised La Paz workshops

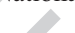

$\begin{array}{ll}\text { Local } & \text { A few local traders } \\ \text { National } & \text { Community enterprise }\end{array}$

Local
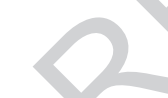

t2.15 Santa Rosa Challana, La Rubber used to Paz, Bolivia

t2.16 Pucasucho, La Paz, Bolivia
Local miners waterporoof bags and ponchos Incense and Copal
Final consumer

Dominance of individuals in the value chain international

International (Japan) Entrepreneur

National and International (North America)

Local, national (international through tourists) International (North America)

Yes, President of the local producers' association

No

National and some international incense to Argentina
Copal in Mexico and
Broad involvement in collection of maguey, but only one family distils serious quantities A small number of traders dominate the purchase of cocoa beans

No

Dominated by concessionaires from outside the community

Apparent effect of Months
the dominance ${ }^{\mathrm{a}} \quad$ traded

2 community

See later

Positive in that this individual has stimulated and maintained new markets

Not enough information to comment

Potential negative impact as these traders limit access to markets with better prices

Concentration of concessions appears to have encouraged investment in processing facilities. But has increased costs of entry to the chain

Negative impact on 12 collector prices and on the environment by not passing on price differentials

See later through tourists)

Local

No 10

t2.18 Carmen Surutú, Sant woven into tourist artefacts Cruz, Bolivia

t2.19 Source: project research. 
378 a total of 15 distinct value chains were examined 379 (see Table 2).

380 For each of the 18 communities in the study a struc381 tured 'community' report was also written, based on 382 secondary information and data collected by partner 383 NGOs using participatory techniques (such as time384 lines, resource mapping, wealth-ranking, Venn dia385 grams) and key informant interviews. The data 386 collected covered a wide range of topics necessary 387 for the understanding of current patterns of resource 388 use and management, with a focus on the collection, 389 cultivation, processing and marketing of the case study 390 NTFP. Both the 'market' and 'community' reports 391 were written by partner NGOs over a 2-year period 392 and finalised in 2003 after much interaction with the 393 project team, interim data analysis and supplementary 394 data collection.

395 A formal household questionnaire was designed to 396 collect data about the household, its use of the NTFP 397 including any costs and benefits incurred, and the 398 interviewee's perception of the household's success 399 and the contribution of NTFPs to their livelihood 400 strategy. During 2002/2003 the project's partner 401 NGOs applied the questionnaire to as many of the 402 households involved in NTFP activities in each com403 munity as agreed to participate. Where more than 20 404 households were involved in NTFP activities, around 40520 households were sampled on the basis of partici406 patory wealth-ranking. In one community (Nueva 407 Santa Flor), trade had ceased as a fungal disease 408 had decimated the resource so no interviews were 409 carried out. In the remaining 17 communities, a total 410 of 289 households were interviewed. A further 117 411 control households not involved in the NTFP activ412 ities were also interviewed. In addition 46 national 413 traders were interviewed using a slightly modified 414 version of the questionnaire. In practice this meant 415 that detailed information was not obtainable for 416 elements of the value chain that extended beyond 417 the national boundaries.

418 Data analysis included comparative text analysis of 419 the community reports, statistical representation and 420 regression analysis of the household data, and con421 struction of value chains (on the basis of the house422 hold data and the market reports) for each product. A 423 detailed presentation of the data collection and analy424 sis methodology is provided in Schreckenberg et al. 425 (2005).

\section{Description of NTFP value chains}

Table 2 provides an overview of the NTFPs included in our research, describing some of the more salient points for each value chain. Key factors that vary between value chains include the distance between producer and consumer, the presence of dominant individuals in the value chain and the number of months the product is traded. The latter also has an effect on the total value added (see te Velde et al., 2004) which varies greatly between different value chains as well as between households in one community trading the same product. For further quantitative information, see Rushton et al. (2004) and te Velde et al. (2004).

\subsection{Value chain maps}

NTFPs differ markedly in ease of collection, required technology and skills for processing, strength of demand, etc. So it is not easy to group them together. There is insufficient space to present all our NTFP value chain maps, so we have focussed on three products: mushrooms, Jipi Japa palm and Camedora palm (for other products see Rushton et al., 2004). These products have been chosen, because they best illustrate the important influences of entrepreneurs in the development of NTFP value chains. There is no standard approach to mapping value chains. In the maps presented here (1 Charts 2 Charts 3) the solid boxes indicate individuals, communities, companies or institutions and the dotted lines indicate an alliance. The arrows represent the flow of products in exchange for money or goods hence the name value chain. Going beyond what is usually presented in value chain maps, these charts show not only the types of activities carried out by different actors (collectors, processors or traders), but also provide information on where each activity takes place.

\subsection{Mushrooms (Oaxaca, Mexico)}

Chart 1 describes the main value chains for four types of mushrooms all collected from the wild in three communities in the state of Oaxaca, Mexico. San Antonio Cuajimoloyas collects three types of mushrooms. Some of these enter a short fresh mushroom
463 


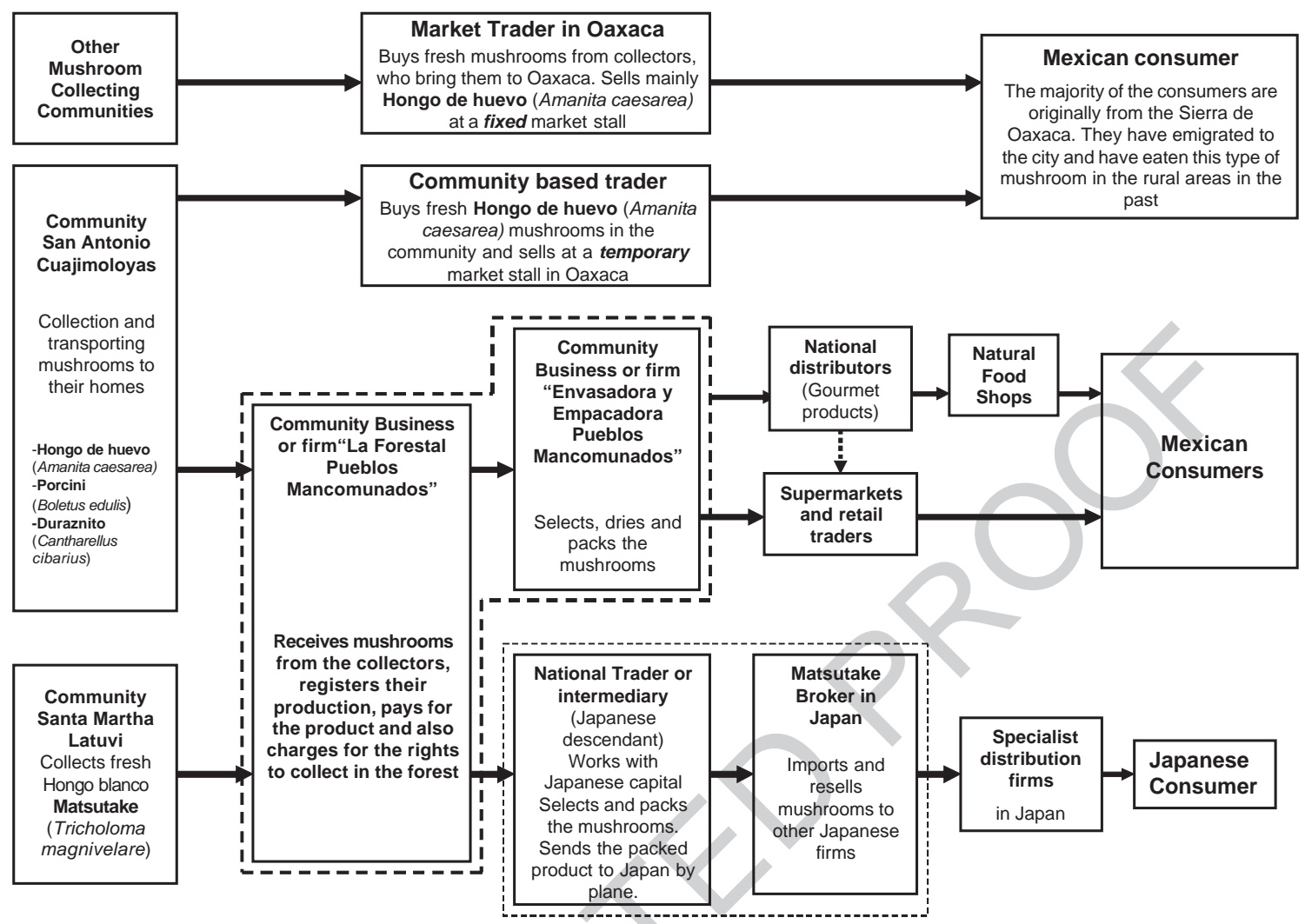

Chart 1. Value chain maps for mushrooms collected in communities close to Oaxaca, Mexico. Source: Rushton et al. (2004).

469 chain ending with local consumers in Oaxaca, while 470 the remainder are dried and enter longer national 471 chains ending with consumers in various large Mex472 ican cities. The community of Santa Martha Latuvi 473 collects only Matsutake mushrooms, which enter the 474 value chain that ends with Japanese consumers in 475 Chart 1 . This value chain is "global" and was initiated 476 by a Korean entrepreneur based in Mexico who had 477 an alliance with two Japanese firms, which provided 478 him with capital to collect, purchase, pack and send 479 Matsutake mushrooms to Japan. This entrepreneur 480 was a critical influence in the development of this 481 value chain but has since retired, being replaced by a 482 Mexican of Japanese descent.

\section{4.3. Jipi Japa palm (Santa Cruz region, Bolivia)}

484 Jipi Japa is a palm (Carludovica palmata), the 485 leaves of which are woven into products such as 486 hats, placemats and bags. During the study of the commercialisation of Jipi Japa products two value chains were identified (see Chart 2). The value chain that links collectors and processors of Jipi Japa from the community El Carmen Surutú with consumers through local shops is the least important in terms of value. The other value chain is dominated by one company, which buys products from 'associate' weavers (all women) in the communities of Potrero San Rafael and Candelaria. This company then sells these products through shops that can reach consumers in various locations including tourists in international airports. The company was established by a dynamic woman who has a strong interest in supporting indigenous ethnic groups, and has played a crucial role in the development of this value chain.

\subsection{Camedora palm (Monte Tinta, Mexico)}

Camedora palm (Chamaedorea spp.) fronds (Chart 3) are a floral product used by European 504 503 


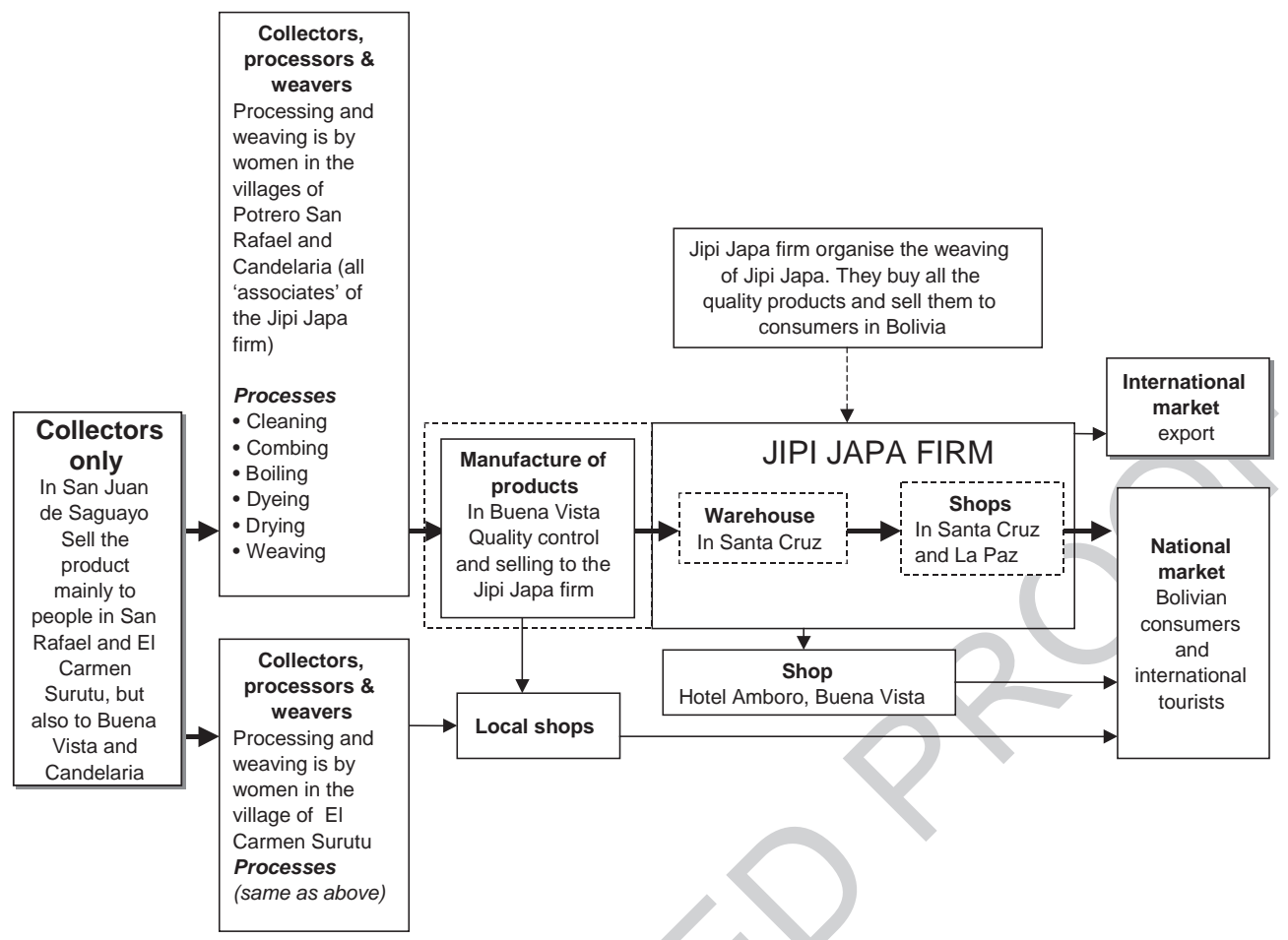

Chart 2. Value chains for Jipi Japa palm (Carludovica palmate), Bolivia. Source: Rushton et al. (2004).

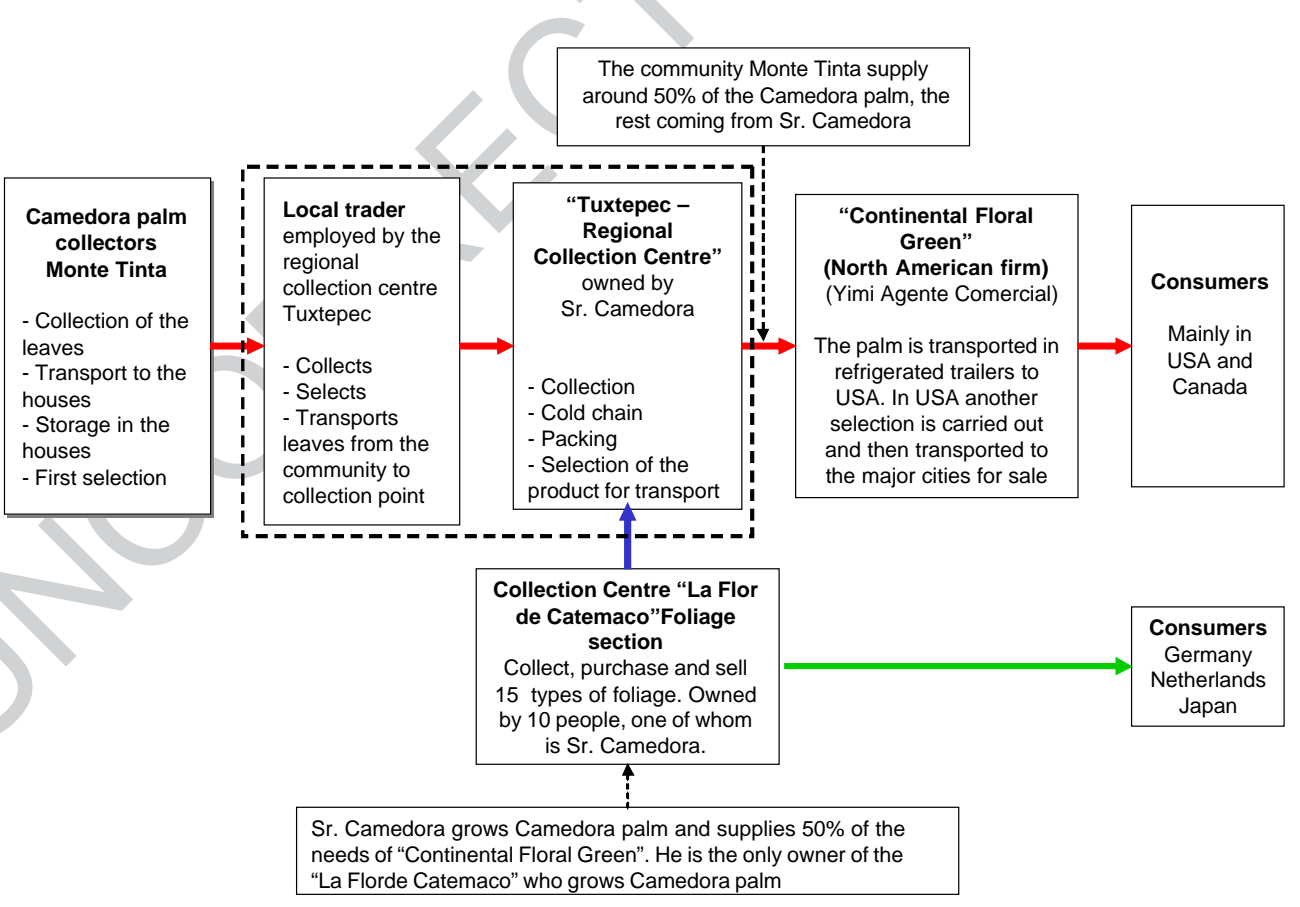

Chart 3. Value chains of Camedora palm (Chamaedorea spp.). Source: Rushton et al. (2004). 
t3.1 Table 3

t3.2 Profits for Matsutake mushrooms (US\$, annual)

$\mathrm{t} 3.4$

t3.5

$\mathrm{t} 3.6$

Source: Rushton et al. (2004).

\begin{tabular}{llcc}
\hline & Collectors & Community firm & Mexican exporter \\
\hline Total & 193 & 7294 & 39,000 \\
Per kg & 12.9 & 4.3 & 25.5 \\
\hline
\end{tabular}

505 and North American consumers. The value chain in 506 Mexico is dominated by one person, who is a repre507 sentative of a North American importing company 508 and owner of a regional collection centre responsible 509 for collecting, selecting and exporting. In addition to 510 purchasing fronds from collectors of the wild palm 511 in the Monte Tinta community, the one-man com512 pany cultivates and supplies half of the required 513 palm. This man has been important in developing 514 other markets for this NTFP in Europe and Japan 515 and his entrepreneurial activities have been key in 516 the general development of the Camedora palm 517 value chain in Mexico.

\section{4.5. Profits along the chain}

519 An alternative way to present a value chain is by 520 analysing the distribution of gains along the chain. 521 Without the objective of being representative or 522 complete for all NTFPs analysed, we computed 523 profits (revenues-costs) for three different actors in 524 the Matsutake mushroom chain as one example. 525 Information for collectors was obtained from the 526 household questionnaires, while data for the com527 munity firm and entrepreneur came from discussions 528 with key informants. Table 3 shows that collectors, 529 the community firm and the exporter earn very 530 different profits. It was not possible to make esti531 mates of the profits for Jipi Japa and Camedora 532 palm value chains. In the case of Jipi Japa, the 533 processing of the product into a large range of 534 differently valued items was such that calculating 535 a unit value of profit was not possible. In both 536 cases the strong position in the value chain of one 537 trader who, as pointed out by Padoch (1992) in her 538 seminal study of NTFP marketing in the Peruvian 539 Amazon, are notoriously difficult to interview, made 540 the collection of data to develop enterprise budgets 541 extremely difficult.

\section{Governance of NTFP value chains}

This section examines in more detail the governance type of the different NTFP value chains and the extent to which they are likely or predicted to be governed by key entrepreneurs downstream from the producer. Section 2 argued that three factors are

Table 4

Knowledge characteristics and governance types of case study value chains

Value chain

Complexity Potential Capabilities Market of interfirm to codify of suppliers governance knowledge knowledge type ${ }^{\mathrm{a}}$ transfer

\begin{tabular}{|c|c|c|c|c|c|}
\hline $\begin{array}{l}\text { Fresh local } \\
\text { mushrooms }\end{array}$ & Low & High & High & Market & $\mathrm{t} 4.4$ \\
\hline $\begin{array}{l}\text { Dried } \\
\text { mushrooms }\end{array}$ & Low & High & High & Market & $\mathrm{t} 4.5$ \\
\hline $\begin{array}{l}\text { Fresh exported } \\
\text { mushrooms }\end{array}$ & High & High & Low & Captive & $\mathrm{t} 4.6$ \\
\hline Pita & Low & High & High & Market & $\mathrm{t} 4.7$ \\
\hline Soyate palm & Low & High & High & Market & $\mathrm{t} 4.8$ \\
\hline Camedora palm & High & High & Low & Captive & $\mathrm{t} 4.9$ \\
\hline Tepejilote palm & Low & High & High & Market & $\mathrm{t} 4.10$ \\
\hline \multirow[t]{2}{*}{ Maguey $^{b}$} & High & Low & High & Relational & $\mathrm{t} 4.11$ \\
\hline & High & Low & Low & Hierarchy & $\mathrm{t} 4.12$ \\
\hline $\begin{array}{l}\text { Organic wild } \\
\text { cocoa }\end{array}$ & High & Low & High & Relational & $\mathrm{t} 4.13$ \\
\hline $\begin{array}{l}\text { Organic cocoa } \\
\text { paste }\end{array}$ & Low & High & High & Market & $\mathrm{t} 4.14$ \\
\hline \multirow{2}{*}{$\begin{array}{l}\text { Natural rubber } \\
\text { latex }^{c}\end{array}$} & Low & High & High & Market & $\mathrm{t} 4.15$ \\
\hline & High & Low & Low & Hierarchy & $\mathrm{t} 4.16$ \\
\hline $\begin{array}{l}\text { Rubberised } \\
\text { products }\end{array}$ & Low & High & High & Market & $\mathrm{t} 4.17$ \\
\hline $\begin{array}{l}\text { Incense and } \\
\text { copal }\end{array}$ & Low & High & Low & $? ?^{\mathrm{d}}$ & $\mathrm{t} 4.18$ \\
\hline $\begin{array}{l}\text { Jipi Japa palm } \\
\text { (tourist } \\
\text { artefacts) }\end{array}$ & High & High & Low & Captive & $\mathrm{t} 4.19$ \\
\hline $\begin{array}{l}\text { Jipi Japa } \\
\text { palm (hats) }\end{array}$ & Low & High & High & Market & $\mathrm{t} 4.20$ \\
\hline
\end{tabular}

${ }^{a}$ As predicted by Gereffi et al. (2003).

b The maguey value chain is relational at the collector and community-based distilling level; but beyond this it becomes hierarchical in nature.

c The latex rubber chain begins as a 'market' type with many labourers available for hire by many rubber concessionaires. Once the latex is collected and moved to the La Paz workshops, the chain becomes more hierarchical.

${ }^{\mathrm{d}}$ Gereffi has no model for this combination of knowledge transfer characteristics. 
548 important in explaining the type of governance of 549 value chains:

550

551 - Complexity of inter-firm information and knowl552 edge transfer.

553 - Potential of codifying information without incur554 ring transaction specific costs.

555 - Capabilities of suppliers.

556

557 Below we explain how we interpreted these factors 558 for the case study value chains, basing our decisions 559 on a combination of quantitative and qualitative data 560 collected for the project. Table 4 then summarises the 561 knowledge transfer characteristics and governance 562 types of all the value chains.

\section{5.1. Complexity of inter-firm information}

564 While it would seem that NTFPs are fairly simple 565 products (although clearly that is not the case for some 566 of the products we researched, e.g. Jipi Japa woven 567 tourist artefacts), this misses an important point. The 568 complexity of products in the eyes of local collectors 569 and processors is not necessarily in the product itself, but in the information required to successfully market the NTFPs, i.e. complexity of inter-firm relationships. Market information is often not readily available to local collectors and they have few contacts further downstream (e.g. how can local collectors establish links with Japanese or American markets?). Hence, selling NTFP products (to actors/consumers downstream) is extremely complex for local collectors and processors.

Evidence that this is so is provided by Chart 4, based on analysis of household questionnaires, which shows that market contacts and market information were considered to be the most important barriers to households selling NTFPs. Market knowledge and contacts are important barriers for most products but detailed project data show that this is particularly so for Camedora palm and Matsutake mushrooms (in Santa Maria Latuvi), so that the score in the first column of Table 4 for most of these products is "high".

Another type of complexity is found in the cocoa and maguey market chains, both of which have very complex social webs close to the production end of the chain. In the cocoa value chain, traders have
570

571

572

573

574

575

576

577

578

579

580

581

582

583

584

585

586

587

588

589

590

591

592

593

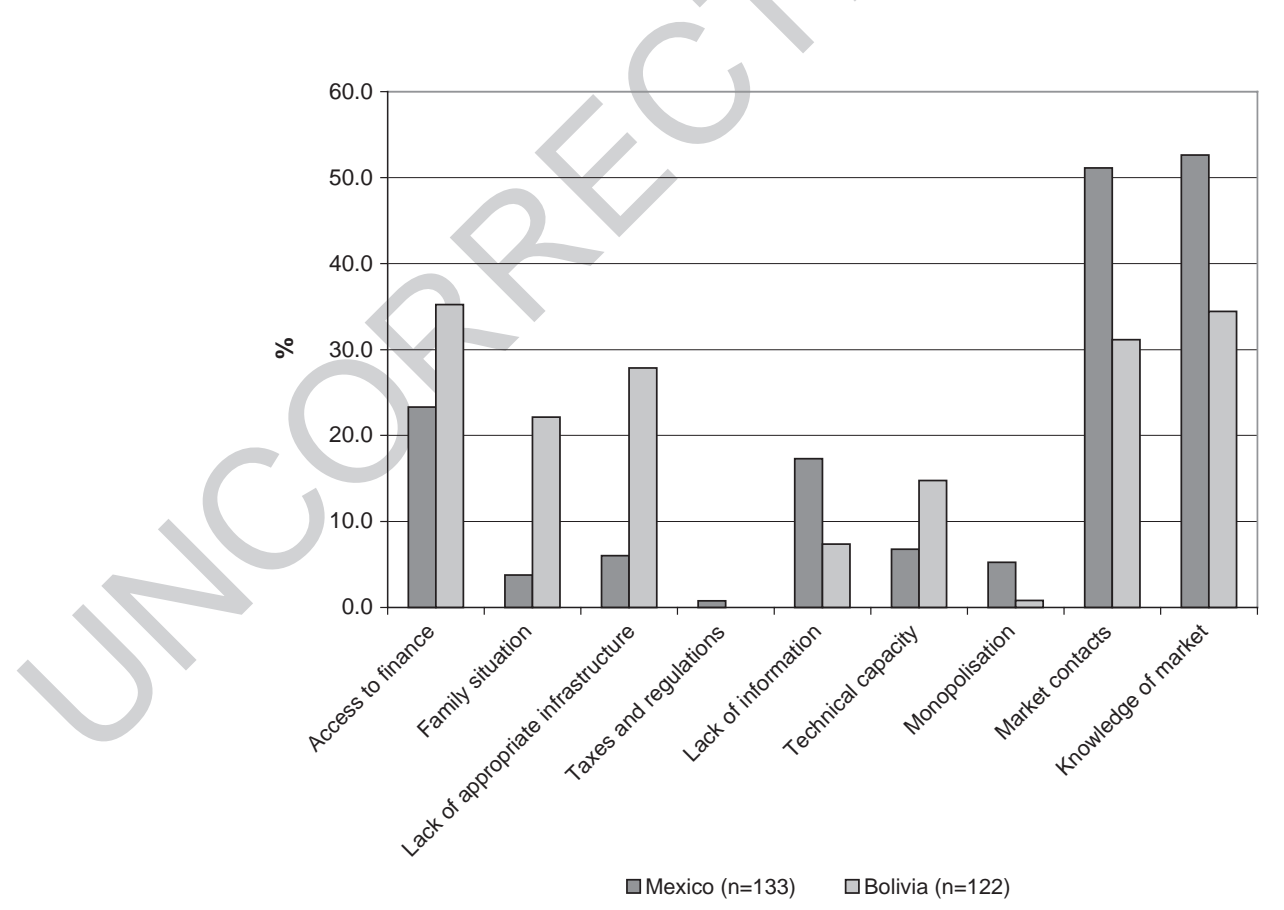

Chart 4. Barriers to selling NTFPs, \% of NTFP households answering yes. Source: te Velde et al. (2004). 
594 intricate relationships with community members,

595 maintaining good relations by being godparents to

596 the children of the community in return for having

597 the right to purchase quality cocoa beans and dried

598 fish. In the maguey value chain, social networks help

599 to determine access to the resource, and mezcaleros

600 (distillers) keep their labour happy with a constant

601 supply of mezcal (in lieu of wages), which is further

602 exchanged as gifts within the community.

603 A more conventional form of complexity is found

604 in the Jipi Japa palm case, where production of the

605 very varied range of tourist items requires women to

606 be highly skilled in dying and weaving techniques.

607 Finally, in the latex rubber case, while the knowledge

608 required to collect the latex itself is fairly simple, the

609 latex is then transported by the owners to $\mathrm{La} \mathrm{Paz}$

610 workshops for processing into a range of highly spe-

611 cialist medical and sporting goods. For the remaining

612 products in Table 4, the complexity of interfirm

613 knowledge transfer is low.

\section{5.2. Potential of codifying inter-firm information}

615 When the lead firm/entrepreneur has acquired the 616 market information it is relatively straightforward to 617 communicate this to actors upstream. For instance, 618 the Jipi Japa firm knows what it sells and commu619 nicates that it wants to purchase this specific range 620 of Jipi Japa products from its suppliers. Nevertheless, 621 given the low capacity of suppliers (see below), the 622 firm has had to invest considerable resources in 623 training to obtain the required quality and in estab624 lishing a system of payments to reward that quality. 625 In the case of Camedora palm, after the importing 626 company had established the links between the 627 American and Mexican markets it was straightfor628 ward to codify the required amount of products to 629 actors upstream in the value chain. The information 630 for Matsutake mushrooms is slightly more complex, 631 but is more easily transmitted to the collectors than 632 in the Jipi Japa case because the mushrooms are 633 purchased on the basis of weight and quality, with 634 no need for processing. It is only in the 'relational' 635 cases mentioned above that the codification of social 636 norms and cultural conventions are difficult to codify 637 in such a way that an outsider to the community 638 could easily understand them. So in most cases the 639 second column in Table 4 is high.

\subsection{Capabilities of suppliers}

640

Gereffi et al. (2003) provide no advice on how to assess the 'capability' of suppliers. In the case of the NTFP value chains studied, the key factors determining whether or not a supplier can meet the requirements of a buyer are their access to the resource, financial capacity and skills base. In some cases, being a member of a producer organisation can help to overcome one or more of these constraints. However, where discussions with communities and key informants suggested that one or more of these remained a serious constraint, the NTFP was graded 'low' in the third column of Table 4.

With respect to resource access, many of the NTFPs were originally collected from communal land to which everybody has access, but have now made the shift to being either collected from, or planted on, plots assigned for individual use (as predicted by Homma, 1996). This accounts for the 'low' rating of incense, for example, where only long-standing members of the community have access to dedicated collecting areas. Furthermore, owners require financial capital to cover the costs of a donkey, hired labour and food for the severalday collecting trips.

Financial capacity is lacking in all the case study communities, which are rural and marginalised in terms of access to markets, information and alternative income-generating activities. Within the communities, NTFP producers are usually amongst the poorer segments as categorised in participatory wealth-ranking exercises that reflected a combination of factors such as people's access to land, remittances, labour and education. In those communities in which only some households were involved in NTFP activities, these households were disproportionately concentrated in the bottom well-being ranking in five communities, amongst the middle ranking in two communities, and in the top ranking for only two communities. One of these was the incense community in which, as described above, only people with some capital can afford the collecting trips. The other was one of the pita communities in which pita is almost entirely domesticated, predominantly by people with the right kind of land and sufficient funds to cover the costs of establishing plantations.

\section{1}

642

643

644

645

646

647

648

649

650

651

652

653

654

655

656

657

658

659

660

661

662

663

664

665

666

667

668

669

670

671

672

673

674

675

676

677

678

679

680

681

682

683

684

685

686 
687 Overall, a third of NTFP households felt that they 688 could not meet their basic needs over the course of a 689 year. In Mexico, NTFP households generally felt 690 themselves to be less successful than other households 691 in their communities with only $6 \%$ feeling more suc692 cessful than their peers. In the Bolivian communities 693 there were few if any alternative income-generating 694 activities and most households relied on the NTFP 695 activity as their only source of cash income. Access to 696 credit is rare in all the case study communities and the 697 provision of credit is one of the most appreciated 698 aspects of the pita producers' cooperative and the 699 Jipi Japa weavers' association.

700 A deficient skills base can also be a serious con701 straint for suppliers. Male heads of NTFP collecting 702 households tend to have less years of formal education 703 compared to non-NTFP households. Many house704 holds are engaged in NTFP activities out of necessity, 705 although households argue that some do play a very 706 useful gap-filling role in their livelihood strategies (te 707 Velde et al., 2004). This would indicate that very few 708 households can become entrepreneurs capable of 709 playing a more important role (e.g. marketing 710 NTFPs to key markets) in NTFP value chains. The 711 reason is that while there are many opportunities for 712 families to be involved in NTFP collection, which 713 require few capital inputs, trading NTFPs tends to 714 have low returns per unit and reasonable incomes 715 can usually only be achieved on the basis of high 716 volumes traded, for which capital to buy, store and 717 transport products is needed (see Chart 4 on capital as 718 a barrier).

719 In effect, the third column in Table 4 essentially 720 splits the case study products into those with lower 721 or higher thresholds of entry (Arnold and Ruiz 722 Pérez, 1996). For the former group the only 723 'capability' a supplier needs, in addition to resource 724 access, is reasonably good health. The second group 725 require either higher levels of skill (Jipi Japa palm 726 tourist artefacts, the downstream levels of the latex 727 rubber chain and the fresh exported mushrooms) 728 and/or up-front capital (Camedora palm, incense 729 and copal, and the downstream level of the maguey 730 value chain). Pita is a slight exception - although up731 front capital is required to establish plantations, the 732 capability of suppliers is generally high as they have 733 relatively easy access to loans for this purpose from 734 the local pita cooperative.

\subsection{Governance types}

735

In conclusion, the analysis of the local collectors and traders for our case study NTFP value chains suggests we can expect NTFPs to fall predominantly into three of the governance types described by Gereffi et al. (2003):

- 'Market' types: these include all the products that are only sold to the local market, often with relatively numerous suppliers and consumers, as well as those with a fairly simple domestic market. For pita and dried mushrooms, the more distant markets are made accessible by the existence of a good community-based producer association.

- 'Relational' types: these are cases (cocoa beans and maguey) in which cultural ties and family networks play a key role in ensuring the success of commercialisation efforts.

- 'Captive' types: these include the three entrepreneur dominated chains (Jipi Japa, tourist artefacts), exported mushrooms and Camedora palm.

The critical factor in determining the governance type would appear to be the physical distance of the consumer from the NTFP collector and the need for specialised skills in processing, marketing and presentation of the product.

The predictions for governance in value chains based on the Gereffi typology relate very well to the type of governance which occurs in practice. For instance, Jipi Japa palm tourist items, exported mushrooms and Camedora palm are characterised by a "high" complexity of inter-firm information for which there exists a "high" potential to codify, while the capabilities of the local communities are considered "low", so that the Gereffi typology would predict a "captive value chain" type of governance. This was indeed what we found when we described these chains in Section 4.

In spite of this concurrence between predicted and actual type of governance, the Gereffi et al. (2003) typology was not always easy to apply to the NTFP cases. It is difficult to apply, for example, where governance changes as you progress along the value chain. This is the case for both maguey and latex rubber, which become "hierarchical" as they approach the consumer. The typology is also difficult to apply
736 737 738 739 740 741 742 743 744 745 746 747 748 749 750 751 752

753 754 755 
782 where the distinction between "firms" is not clear, as

783 frequently occurs in NTFPs that are first traded in the

784 informal sector and only move into the formal sector

785 when they cross national boundaries. It may also need

786 to be applied in a more differentiated manner if it is to

787 help distinguish the different forms of governance that

788 may be found in producer level organisations (which

789 are of particular interest to policy-makers). Here we

790 came across three very different types, all of which,

791 however, provided benefits to producers and played

792 an important role in supporting the viability of the

793 value chain: (i) in the pita case the producer coopera-

794 tive is run by a pita producer and members have a say

795 in the management; (ii) in the Jipi Japa palm case, the

796 association is an institution set up by the trading

797 company to assure its supply and giving members

798 no say in decision-making; (iii) in the dried and

799 exported mushroom cases, the community enterprise

800 is run by a hired business manager who can be fired

801 by the community. Finally it should be noted that

802 governance changes over time (e.g. in the pita case,

803 dominance by a strong individual has given way to a

804 much more open market) and a different type may

805 apply in the early and later stages of value chain

806 establishment.

\section{6. Entrepreneurship and upgrading in value chains}

808 As discussed above, captive value chains were

809 associated with significant upgrading of East Asian

810 suppliers of textiles and garments, while certain parts

811 of the furniture value chain in South Africa were

812 locked out of the captive value chain. This section

813 discusses whether entrepreneurship and upgrading

814 was evident in captive value chains of NTFPs.

815 We find that entrepreneurship was indeed impor-

816 tant in the 'captive' value chains (Jipi Japa palm

817 tourist artefacts, Camedora palm and exported Matsu-

818 take mushrooms). An important question then is

819 whether such captive value chains should be pre-

820 vented or controlled, i.e. do these entrepreneurs

821 exploit collectors and processors upstream, particu-

822 larly since given the characteristics of complexity,

823 codification and capabilities we would expect a cap-

824 tive value chain anyway?

825 Our research suggests that these entrepreneurs are

826 actually key actors in driving the whole of the chain (as did the lead firms in the textiles and garments value chain in East Asia). Without them, the value chain might either not have existed or entrepreneurship throughout the chain would be less advanced, although in some instances there is evidence of a "lock-in" situation where suppliers are locked into certain production functions while in other instances potential suppliers are simply excluded from more successful value chains (as in the case of pine furniture in South Africa). It is noted that these value chains are relatively new (all less than 10 years) and the concern that these individuals are abusing their powerful position, or may limit future development of the chain, is best examined product by product.

\subsection{Jipi Japa}

In the case of Jipi Japa palm, the dominant firm is much more than a buyer and seller. It has a quality control system, markets the products to nationals and tourists, offers training to local weavers and provides several social functions such as funds for housing development. This firm maintains a high-trust relationship with local suppliers (the Jipi Japa weavers), who have benefited through an improvement in their production processes and opportunities to sell their products. However, there are a few negative aspects of this "captive" value chain. The Jipi Japa firm demands only products that fit into its shop (small, colourful and relatively cheap Jipi Japa products perform an important function of attracting tourists into the shop where they may go on to purchase other much higher value artisanal products) and suppliers are not encouraged to innovate and make higher value added products since the firm lacks the marketing channels to sell these products. The "switching costs" to alternative buyers by the Jipi Japa processors would be high as there are few about and none that could provide the same level of non-income benefits (health care, training, status, access to credit) that the association established by the Jipi Japa firm provides. Hence, while the Jipi Japa firm has been essential for process upgrading of existing products in the upstream part of the value chain, it also stifles functional upgrading upstream (i.e. marketing of higher value added products). Further there is exclusion. The weavers in one community, who are from a different ethnic 
873 group, were reported to be excluded from this value

874 chain and the associated marketing channels. This

875 community sells hats to local people, which is a less 876 attractive market.

\section{6.2. Matsutake mushrooms}

878 This case is simple: without the key entrepreneurs 879 there would be no contacts between Mexico and Japan 880 and there would be no niche market for Mexican 881 Matsutake mushrooms. The entrepreneurs have there882 fore been responsible for chain upgrading. Actors 883 upstream, including local collectors, make a welcome 884 profit (Table 3). The question of whether the traders 885 are making "super" profits is difficult to assess as the 886 time taken to establish a position in the market and the 887 risks incurred (e.g. advancing the costs of air-freight 888 to Japan) were not available. However, during the 889 two-year study period a trader entered and left the 890 market, which indicates that even with high estimated 891 profits at the national trader level, this is not an easy 892 market to capture or maintain.

\section{6.3. Camedora palm}

894 In the Camedora palm value chain a key entre895 preneur established the link between Mexico and the 896 North American market. This link and the position 897 of this entrepreneur within the chain are the result of 898 his many years of work in the sector as well as 899 training and financial support received from his 900 American buyer. These have also enabled him to 901 carry out process upgrading, including the produc902 tion of better and more consistent quality fronds 903 through domestication. This captive value chain 904 also appears to have negative aspects: because the 905 entrepreneur himself cultivates half the Camedora 906 palm required, i.e. he is both a buyer and supplier. 907 To some extent, therefore, he can exert his market 908 power over the other suppliers. The prices paid to 909 the collectors are so low that they only engage in the 910 activity for 6 months of the year, whereas his culti911 vated supplies sustain the value chain for the rest of 912 the year. Some evidence for the dissatisfaction this 913 causes can be seen in the fact that all households 914 engaged in collecting Camedora palm wanted to sell 915 their product to the part of the chain above this 916 entrepreneur.

\section{Discussion and conclusions}

The paper has examined the role of entrepreneurship in NTFP commercialisation through the lens of (global) value chains, which is novel in terms of its application to NTFPs. Value chain analysis has emerged as a new way of understanding markets for commodities. We have applied the analysis successfully to the market for NTFPs by (1) drawing value chain maps; (2) providing an example of distribution of profits along the chain; (3) predicting for NTFP value chains what type of governance we can expect in theory and what type has occurred in practice; and (4) discussing the effects of the type of governance for entrepreneurship in the value chain for three NTFPs. However, there are limits to some aspects of this methodology, particularly quantitative analysis, where the collection of data to develop profit distributions is made difficult by the sensitive nature of the information. To be effective as a methodology that helps to direct policy these data collection issues need to be overcome as one of the critical issues in the chains analysed is the powerful position of key individuals and firms.

Our analysis of NTFP commercialisation has shown that entrepreneurs are important in the development of innovative marketing of NTFPs and are often key to spreading success throughout the value chain. Typical examples include the company in Santa Cruz which supports many producers by moving their woven palm products into the tourist market, and the entrepreneur in Mexico who established links between mushroom pickers in rural communities and brokers and consumers in Japan. Entrepreneurship appears to be particularly critical where markets and consumers are physically distant from collectors.

Based on these conclusions, we suggest that it can be shortsighted to criticise the monopolistic position of such individuals. Instead, thought should be given to how they might be supported in order to increase the positive impacts of their innovation and entrepreneurship within the value chains. At the same time, it would be unwise not to consider ways of limiting the potential negative aspects of their powerful positions within these chains. As the analysis has shown, the negative effects differ from case to case. Therefore projects to support the com-
918

919

920

921

922

923

924

925

926

927

928

929

930

931

932

933

934

935

936

937

938

939

940

941

942

943

944

945

946

947

948

949

950

951

952

953

954

955

956

957

958

959

960

961

962

963 
964 mercialisation of specific NTFPs need to be 965 designed to take into account the activities and 966 attitudes of the key individuals. The experience of 967 the project's partners suggests that some local orga968 nisation now have the capacity to provide the neces969 sary flexible and differentiated support on a case-by970 case basis. More generally, producer communities 971 can be empowered to understand (and monitor) 972 the role of downstream intermediaries and improve 973 their bargaining position through the provision of 974 organisational support and improved market infor975 mation systems. Better education and access to 976 credit (especially for NTFP-based enterprises), com977 bined with a simpler and more transparent system of 978 regulations (for those products for which collection 979 and/or various export permits are required) can help 980 existing entrepreneurs as well as opening up the 981 playing field for new actors to take on the entre982 preneurial role.

\section{Acknowledgements}

984 The authors thank the communities and traders 985 who participated in this work. Names of individuals 986 have been changed to preserve their anonymity. We 987 also thank two anonymous reviewers for their sug988 gested improvements to the paper. This publication is 989 an output from a research project funded by the Uni990 ted Kingdom Department for International Develop991 ment (DFID) for the benefit of developing countries. 992 The views expressed are not necessarily those of 993 DFID. Project R7925 Forestry Research Programme.

\section{References}

995

996 Arnold, J.E.M., Ruiz Pérez, M., 1996. Framing the issues relating to

1001 Belcher, B., Schreckenberg, K., 2003. NTFP commercialisation: a 1002 reality check. Paper presented to NWFP side event, World 1003 Forestry Congress, Quebec, 20 September 2003.

1004 Corry, S., 1993. 'Harvest Moonshine' Taking You for a Ride. 1005 Survival International, London.

1006 Dolan, C., Humphrey, J., Harris-Pascal, C., 1999. Horticulture 1007 commodity chains: the impact of the UK market on the African 1008 fresh vegetable industry. IDS Working Paper 96.
Gereffi, G., 1999. International trade and industrial upgrading in the apparel commodity chain. Journal of International Economics $28,37-70$.

Gereffi, G., Humphrey, J., Sturgeon, T., 2003. The governance of global value chains. Forthcoming in Review of International Political Economy, available from http://www.ids.ac.uk/ globalvaluechains/publications/govgvesfinal.pdf.

Homma, A.K.O., 1996. Modernisation and technological dualism in the extractive economy in Amazonia. In: Ruiz Pérez, M., Arnold, J.E.M. (Eds.), Current Issues in Non-Timber Forest Products Research. Center for International Forestry Research, Bogor, Indonesia, pp. 59-82.

Humphrey, L., 2000. Which way to market? Exploring opportunities for marginalized producers in developing countries to supply mainstream commercial companies in the UK. Traidcraft Policy Unit Report Series No. 1. Traidcraft, UK.

Humphrey, J., Schmitz, H., 2001. Governance in global value chains. IDS Bulletin $32 \mathrm{http}: / / w w w . i d s . a c . u k / g l o b a l v a l u e c h a i n s /$ publications/HumphreySchmitz.pdf.

Kaplinsky, R., 2000. Spreading the gains from globalisation: what can be learned from value chain analysis. IDS Working Paper 110.

Kaplinsky, R., Morris, M., 2001. A Handbook for Value Chain Research. Report Prepared for IDRC.

Kaplinsky, R., Memedovic, O., Morris, M., Readman, J., 2003. The Global Wood Furniture value chain: what prospects for upgrading by developing countries? UNIDO Sectoral Studies Series. www.unido.org.

Marshall, E., Newton, A.C., Schreckenberg, K., 2003. Commercialising non-timber forest products: first steps in analysing the factors influencing success. International Forestry Review 5 (2), $128-137$.

Maynard, B., Blowfield, M., Burchell, R., Collinson, C., Nelson, V., Tallontire, A., Thornback, J., 2001. Ethical Trade, People and Forests: A Manual. Natural resources Institute, University of Greenwich, UK.

Neumann, R.P., Hirsch, E., 2000. Commercialisation of NonTimber Forest Products: Review and Analysis of Research. Center for International Forestry Research, Bogor, Indonesia. $176 \mathrm{pp}$.

Padoch, C., 1992. Marketing of non-timber forest products in Western Amazonia: general observations and research priorities. In: Nepstad, D.C., Schwartzman, S. (Eds.), Non-Timber Products from Tropical Forests: Evaluation of a Conservation and Development Strategy. Advances in Economic Botany, vol. 9. The New York Botanical Garden, Bronx, NY, pp. 43-50.

Porter, M.E., 1985. Competitive Advantage. The Free Press, New York.

Ruiz Pérez, M., Arnold, J.E.M. (Eds.), 1996. Current Issues in NonTimber Forest Products Research. Center for International Forestry Research, Bogor, Indonesia, pp. 1-18.

Ruiz Pérez, M., Byron, N., 1999. A methodology to analyze divergent case studies of non-timber forest products and their development potential. Forest Science 45 (1), 1-14.

Ruiz Pérez, M., Belcher, B., et al., 2004. Markets drive the specialization strategies of forest peoples. Ecology and Society 9 (2), 4 http://www.ecologyandsociety.org/vol9/iss2/art4.
1009

1010

1011

1012

1013

1014

1015

1016

1017

1018

1019

1020

1021

1022

1023

1024

1025

1026

1027

1028

1029

1030

1031

1032

1033

1034

1035

1036

1037

1038

1039

1040

1041

1042

1043

1044

1045

1046

1047

1048

1049

1050

1051

1052

1053

1054

1055

1056

1057

1058

1059

1060

1061

1062

1063

1064

1065 
1066 Rushton, J., Perez, L., Viscarra, C., 2004. Marketing chains for a 1067 range of non-timber forest products in Bolivia and Mexico. 1068 Project Report. Overseas Development Institute, London.

1069 Schreckenberg, K., 2003. Appropriate ownership models for natural 1070 product-based small and medium enterprises in Namibia. Con1071 sultancy Report for the Ministry of Trade and Industry, Wind1072 hoek, Namibia.

1073 Schreckenberg, K. et al., 2005. Methodological Procedures. Project 1074 Report. Overseas Development Institute, London.

1075 Schwartzman, S., 1992. Social movements and natural resource 1076 conservation in the Brazilian Amazon. In: Counsell, S., Rice, 1077 T. (Eds.), The Rainforest Harvest: Sustainable Strategies for 1089
Saving the Tropical Forests? Friends of the Earth, London, 1078 pp. 207-212.

te Velde, D.W., other project participants 2004. Successful NTFP commercialisation: a quantitative analysis based on household and trader level data. Project Report. Overseas Development Institute, London.

UNIDO, 2002. Industrial Development Report 2002/2003: Competing through Innovation and Learning. UNIDO, Vienna. Wollenberg, E., Ingles, A. (Eds.), 1998, Incomes from the Forest. Methods for the Development and Conservation of Forest Products for Local Communities. CIFOR, Bogor, Indonesia.
1079

1080 1081 1082 1083 1084 1085 1086 1087 1088 